\title{
Six Years Major Historical Urban Floods in West Bengal State in India: Comparative Analysis Using Neuro- Genetic Model
}

\author{
Nihar R. Samal ${ }^{1,2, *}$, Pankaj K. Roy ${ }^{3}$, Mrinmoy Majumadar ${ }^{3}$, S. Bhattacharya ${ }^{2}$, Malabika Biswasroy ${ }^{3}$ \\ ${ }^{1}$ CUNY Institute for Sustainable Cities, Hunter College, City University of New York, 695 Park Ave., New York, NY, USA \\ ${ }^{2}$ Department of Civil Engineering, National Institute of Technology Durgapur, M.G. Avenue, Durgapur, West Bengal, India \\ ${ }^{3}$ School of Water Resources Engineering, Jadavpur University, Kolkata, West Bengal, India \\ *Corresponding author: samalnr@gmail.com
}

Received June 20, 2013; Revised January 24, 2014; Accepted May 29, 2014

\begin{abstract}
An estimated 96 percent of deaths related to natural disasters in the past decade occurred in developing countries. Flooding is one of the greatest water-related environmental disasters and is the major concern in West Bengal state in India. The number of people vulnerable to devastating floods is expected to rise due to large-scale urbanization, population growth in flood-prone areas, land use changes, climate change and rising sea levels apart from its contributions to the biodiversity and sustainability of ecosystems and to many human activities. New disaster risk reduction approaches are needed to build the necessary capacity to address these challenges. Based on this context, an investigation is made in the state of West Bengal in India over six years of extreme rainfall event highlighting the flooding situation interlinked with the structural and non-structural measures and its management strategy. West Bengal State experience heavy precipitation particularly in the months of September and October consequently upon low pressure/depressions developed in the Bay of Bengal during the years 1956, 1959, 1978, 1995, 1999 and 2000, which faced such worst type of rainfall and the year 2000 may be designated as the year of the worst precipitation in terms of quantum, intensity and duration. Lack of control structures coupled with very high discharge in the rivers during the year 2000 resulted in prolonged agony for a large number of people within the state. It is also attempted to develop a neuro-genetic models to identify the relationship between return period and extreme rainfall event.
\end{abstract}

Keywords: flood-prone areas, extreme rainfall event, disaster, return period, neuro-genetic models

Cite This Article: Nihar R. Samal, Pankaj K. Roy, Mrinmoy Majumadar, S. Bhattacharya, and Malabika Biswasroy, "Six Years Major Historical Urban Floods in West Bengal State in India: Comparative Analysis Using Neuro-Genetic Model.” American Journal of Water Resources, vol. 2, no. 2 (2014): 41-53. doi: 10.12691/ajwr-2-2-3.

\section{Introduction}

Northeast India and west coast are the two major disaster prone regions of India because of their unique geographical locations and physical features, witnessing the fury of monsoon. The summer (southwest) monsoon influences both these region from June to September contributing more than $80 \%$ of the annual rainfall. During this season major floods occur that often lead to disaster in urban areas. A flood is an extreme event, having major impact on humanity and also on the environment. As extreme events deviate beyond the threshold of tolerance, they create a progressively greater potential for disaster [1]. The physical and socioeconomic impacts of disaster are complex, depending upon the vulnerability of the place of occurrence as well as the mitigation strategies [2]. The vulnerability of the people to the extreme weather events seems to be increasing every year in terms of change in intensity and frequency $[3,4]$, that adversely affecting human beings and their interaction with different urban ecosystems [5-11]. Therefore, the studies related to climatic change and extreme weather events have received increased attention in the last few years. Several researchers reported the genesis of flood hazards $[12,13]$ and attributed it to the social, natural, climatological and synoptic factors [14]. Historically, floods have produced the greatest death tolls than any other natural hazards [15].

The state West Bengal, by virtue of its geographical position at the tail end of the vast Ganga basin is very adversely situated if flood, drainage and erosion problems are considered. The state extends from the snow-capped mountains of the Himalayas to the Bay of Bengal and manifests every aspect of floods and drainage problems. The districts in the southern parts of the State namely the Gangetic West Bengal experience heavy precipitation particularly in the months of September and October consequently upon low pressure/depressions developed in the Bay of Bengal during the major flood years 1956, 1959, 1978, 1995, 1999 and 2000, which faced such worst type of rainfall and the year 2000 may be designated as 
the year of the worst precipitation in terms of quantum, intensity and duration [16]. Changes in long term weather and the impact of climate change [17] becomes the major reason of urban flooding, which ultimately affects the internal dynamics of lakes and reservoirs ecosystem $[18,19,20,21]$. The complexity of urban hydrology is different from forest and watershed hydrology. Based on this context, an investigation is made in the state of West Bengal in India over six years of extreme rainfall event highlighting the flooding situation interlinked with the structural and non-structural measures and its management strategy. It is also attempted to develop a neuro-genetic models to identify the relationship between return period and extreme rainfall event. Lack of control structures coupled with very high discharge in the rivers during the year 2000 resulted in prolonged agony for a large number of people within the state.

\section{Materials and Methods}

\subsection{Study Area}

West Bengal has 18 districts and Kolkata serves as the state capital shown in Figure 1. There are over 23 towns with a population of over 100,000. The largest cities are Kolkata, Howrah, Asansol, Durgapur and Siliguri. Other important towns include Darjeeling, Kharagpur and Haldia. Kolkata is amongst the largest metropolitan regions in the world. The state has international boundaries with Bangladesh, Bhutan and Nepal. The present investigation is mainly concentrated with the districts, such as Birbhum, Bankura, Bardhaman, Murshidabad and north and south 24-parganas, which are flood-prone areas and its daily rainfall data is considered for the analysis.

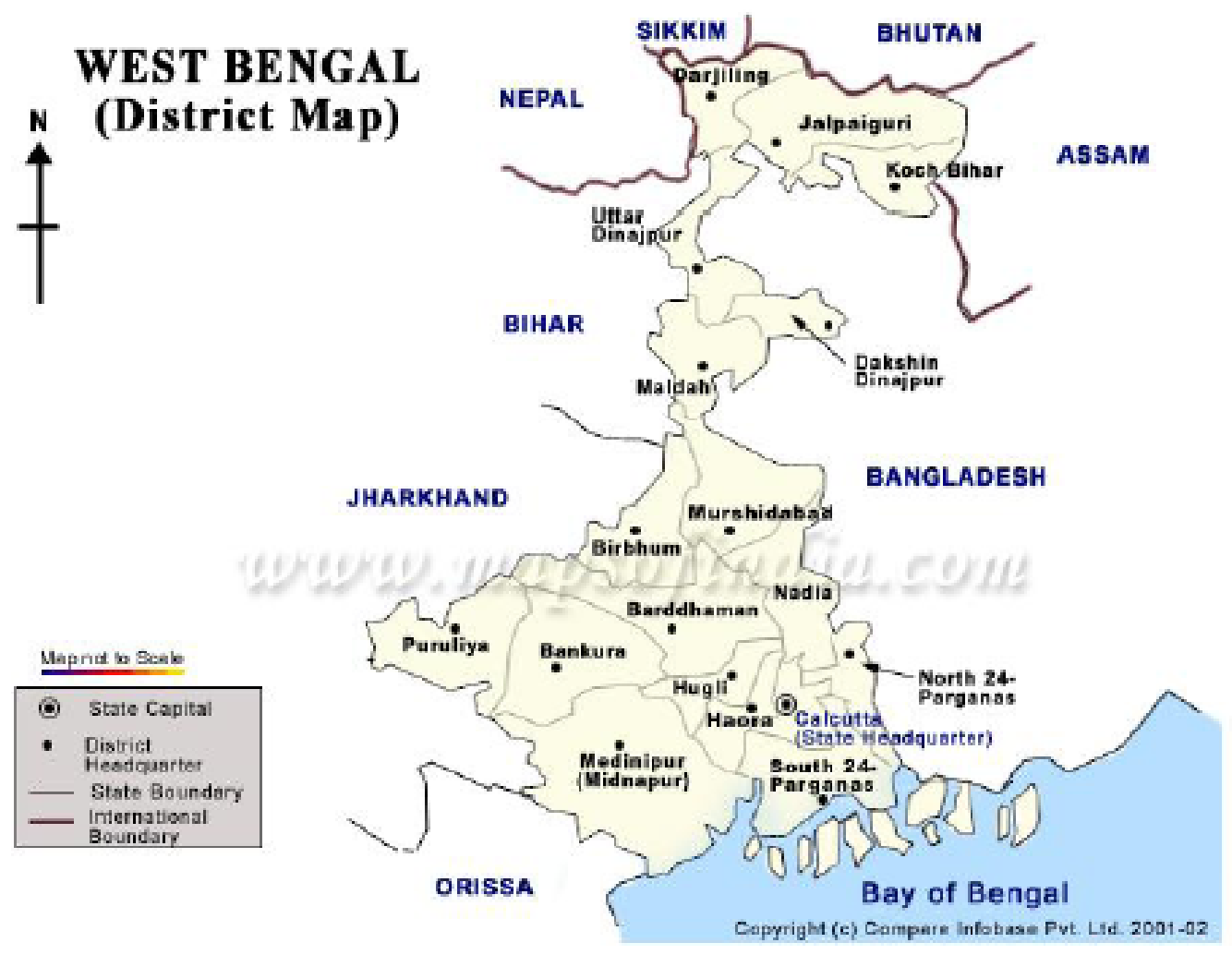

Figure 1. Map of the study area showing the flood-prone districts in West Bengal

The land use pattern (detailed in Figure 2) in these districts also plays a dominant role in controlling the micro-climate of the area, which had direct bearing on the vegetation and crop yield.

\subsection{Rainfall Pattern in the West Bengal State}

Considering the rainfall pattern in West Bengal (Figure 3) there exists quite diversity between the rainfall in the Himalayas and the Gangetic planes [22]. Jalpaiguri has the highest amount of rainfall of $5323 \mathrm{~mm}$ annually whereas Bankura has the lowest with $1119 \mathrm{~mm}$ annually. Monsoon in West Bengal generally stretches from June to September. $95 \%$ of the total rainfall occurs during this span of time due to the monsoon winds. These wind formation starts roughly from end of May to the first week of June and recedes as September heads to a close. Every year due to heavy flood occurrence many places in West Bengal are adversely affected and are accountable for a large loss of life and property. Some of the years where extensive flood occurrence are 1913, 1942, 1954, 1965, 1956, 1959, 1978, 1993, 1995, 1999, 2000. Some of the reasons for flood occurrence in West Bengal are:

1. The intensity and the amount of rainfall in West Bengal are correspondingly quite high.

2. Landslides in mountain areas.

3. Frequent breakage of the river banks and embankments.

4. Excess silt deposit along with boulders and sand particles which hampers the natural river flow.

5. Soil erosion in mountains.

6. Frequent change in the course of the rivers.

\subsection{Data Acquisition}

All the meteorological data were collected from two major websites viz. Www.indiawaterportal.org and www.imd.org. All the data provided in the former 
website were in the form of annual and monthly data whereas the data available in IMD site were in the daily format and a distinction between the daily rainfall and seasonal rainfall is well chalked out. The data for the literature part were obtained from the magazines published by the Irrigation \& Waterways Department of

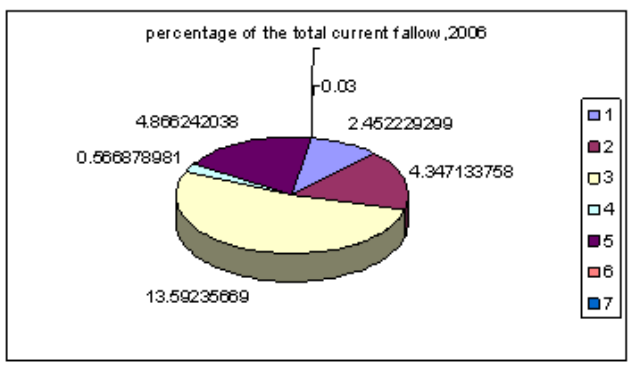

a

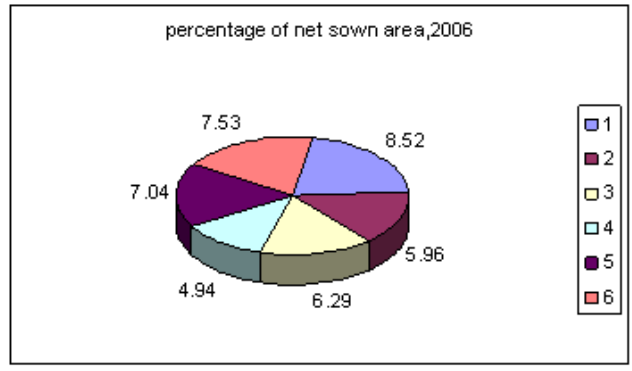

$\mathrm{c}$

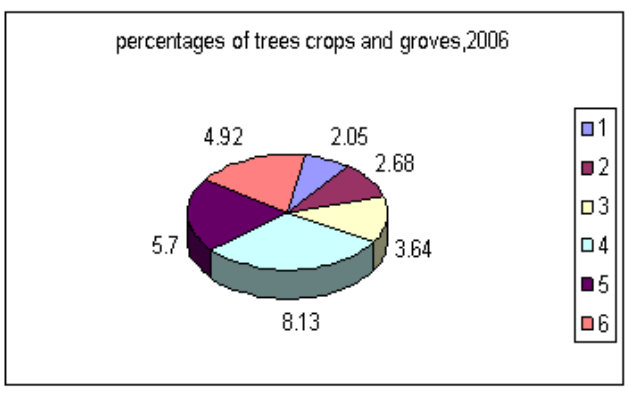

e

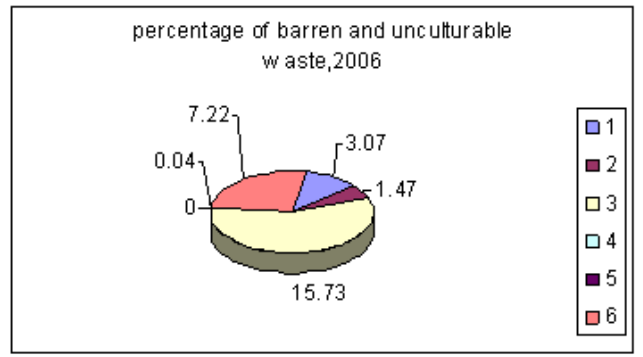

g
West Bengal titled Sechpatra editions 1997, 1998, 1999 and 2000 [16]. The data regarding the modeling and the theories of the relationship between rainfall runoff $[23,24]$, flood forecasting [25] and all the other relevant hydrological data are obtained and followed as described elsewhere [26,27].
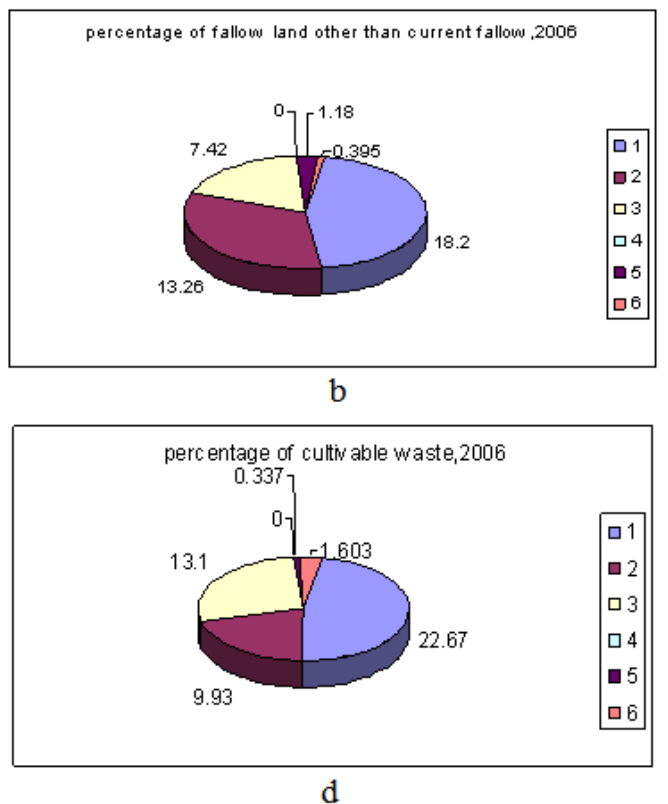

percentage of permanent pastures and grazing lands,2006

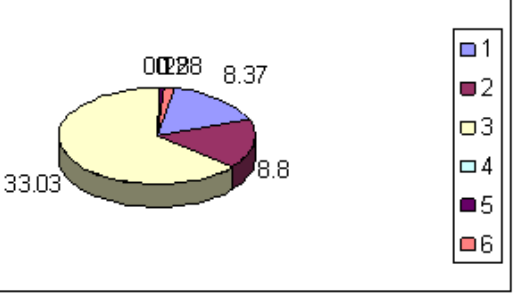

f

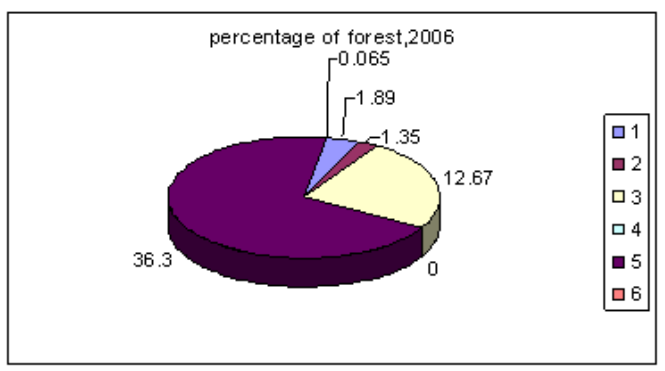

$\mathrm{h}$

Figure 2. Land use pattern in the flood-prone districts in West Bengal (in the Figure 1, Figure 2, Figure 3, Figure 4, Figure 5, Figure 6 represent Bardhaman, Birbhum, and Bankura, north and south 24-parganas and Murshidabad)

\subsubsection{Data Analysis and Treatment}

\subsubsection{Calculation of Return Period}

In many hydraulic engineering applications such as those concerned with flood, the probability of occurrence of a particular extreme rainfall; e.g. a $24 \mathrm{hr}$ maximum rainfall will be of much importance. Such information is obtained by frequency analysis of point data rainfall. The rainfall in a place is random hydrological process and a sequence of rainfall data at a place when arranged in a chronological order constitutes a time series. The probability of occurrence of an event of a random variable whose magnitude is equal to or in excess of a specified magnitude $\mathrm{X}$ is denoted by $\mathrm{P}$. The return period is defined as $T=1 / P$. This represents the average interval between the occurrence of a rainfall of magnitude equal to or greater than $X$ [26]. Thus if the return period is said to be 5 years for a rainfall of intensity of $50 \mathrm{~m} / \mathrm{hr}$ then it implies that at the particular location a rainfall of that same intensity or more will occur once in 5 years and the probability of that rainfall is $1 / 5$ which is 0.2 . The graphs shown below (Figure 4) are a representation of the expected return periods and probability of occurrences in the area of interest. 


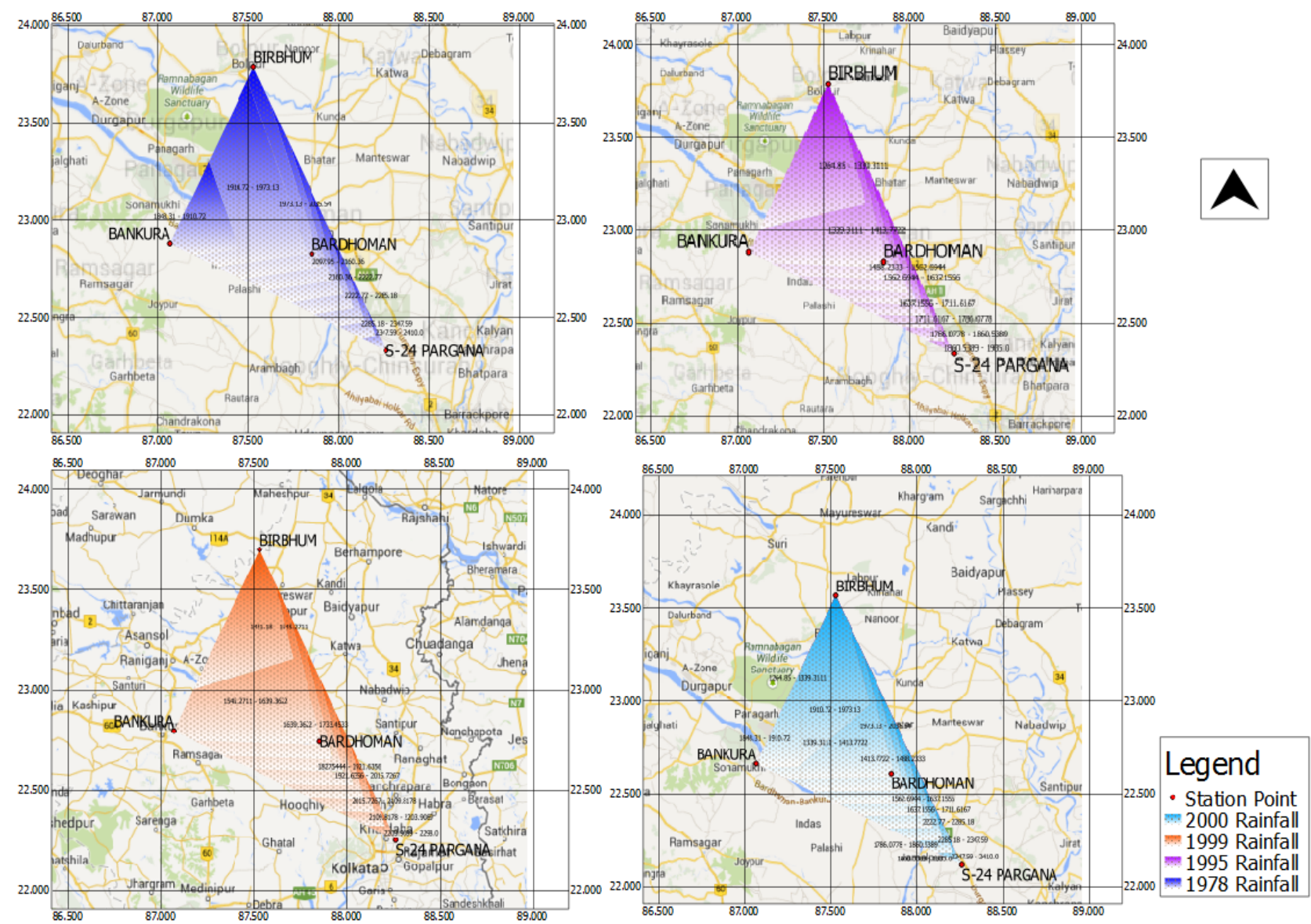

Figure 3. Representation of the expected return periods and probability of occurrences of rainfall event [Rainfall (mm) \& Return period (Year)]

1. The case of Birbhum the calculation of return period is shown from the year spanning from 1982 to 2002. The maximum amount of rainfall which occurred during that period was $1902.72 \mathrm{~mm}$ (annual value) corresponding to a return period of 22 years and a probability of occurrence of 0.04545 while the minimum rainfall during the period was $999.27 \mathrm{~mm}$ corresponding to a return period of 1.1 years and a probability of 0.9 . There are six years of consideration that is 1956, 1959, 1978, 1995, 1999, 2000 whose annual rainfall are obtained as 1752.2 $\mathrm{mm}, 1553.85 \mathrm{~mm}, 1982.26 \mathrm{~mm}, 1264.85 \mathrm{~mm}$, $1451.18 \mathrm{~mm}$ and $1057.1 \mathrm{~mm}$ along with their intensities during the flood period and the respective return period is calculated with the aid of the graph obtained.

2. The case of Bankura the calculation of return period is shown from the year spanning from 1982 to 2002. The maximum amount of rainfall which occurred during that period was $1856.02 \mathrm{~mm}$ (annual value) corresponding to a return period of 22 years and a probability of occurrence of 0.04545 while the minimum rainfall during the period was $1048.47 \mathrm{~mm}$ corresponding to a return period of 1.047 years and a probability of 0.954 . There are three years of consideration that is 1959, 1978, 1999 whose annual rainfall are obtained as $1352.47 \mathrm{~mm}, 1848.31 \mathrm{~mm}$ and $1573.14 \mathrm{~mm}$ along with their intensities during the flood period and the respective return period is calculated with the aid of the graph obtained.

3. The case of Bardhaman the calculation of return period is shown from the year spanning from 1982 to
2002. The maximum amount of rainfall which occurred during that period was $1938.55 \mathrm{~mm}$ (annual value) corresponding to a return period of 22 years and a probability of occurrence of 0.04545 while the minimum rainfall during the period was $1332.76 \mathrm{~mm}$ corresponding to a return period of 1.69 years and a probability of 0.59 . There are three years of consideration that is 1978, 1999, 2000 whose annual rainfall are obtained as $1997.08 \mathrm{~mm}, 1616.96 \mathrm{~mm}$ and $1137.44 \mathrm{~mm}$ along with their intensities during the flood period and the respective return period is calculated with the aid of the graph obtained.

4. The case of Murshidabad the calculation of return period is shown from the year spanning from 1976 to 1995. The maximum amount of rainfall which occurred during that period was $1915.14 \mathrm{~mm}$ (annual value) corresponding to a return period of 21 years and a probability of occurrence of 0.0476 while the minimum rainfall during the period was $1081.5 \mathrm{~mm}$ corresponding to a return period of 1.05 years and a probability of 0.952 . There are four years of consideration that is 1956, 1959, 1978, 1995 whose annual rainfall are obtained as $1729.19 \mathrm{~mm}$, $1690.221 \mathrm{~mm}, 1820.42 \mathrm{~mm}$ and $1446.88 \mathrm{~mm}$ along with their intensities during the flood period and the respective return period is calculated with the aid of the graph obtained.

5. The case of 24-parganas the calculation of return period is shown from the year spanning from 1982 to 2002. The maximum amount of rainfall which occurred during that period was $2235.34 \mathrm{~mm}$ (annual value) corresponding to a return period of 22 years 
and a probability of occurrence of 0.04545 while the minimum rainfall during the period was $1162.56 \mathrm{~mm}$ corresponding to a return period of 1.1 years and a probability of 0.9 . There are four years of consideration that is 1956, 1959, 1978, 1995 whose annual rainfall are obtained as $1809.81 \mathrm{~mm}, 1953.63$ $\mathrm{mm}, 2217.64 \mathrm{~mm}$ and $1842.64 \mathrm{~mm}$ along with their

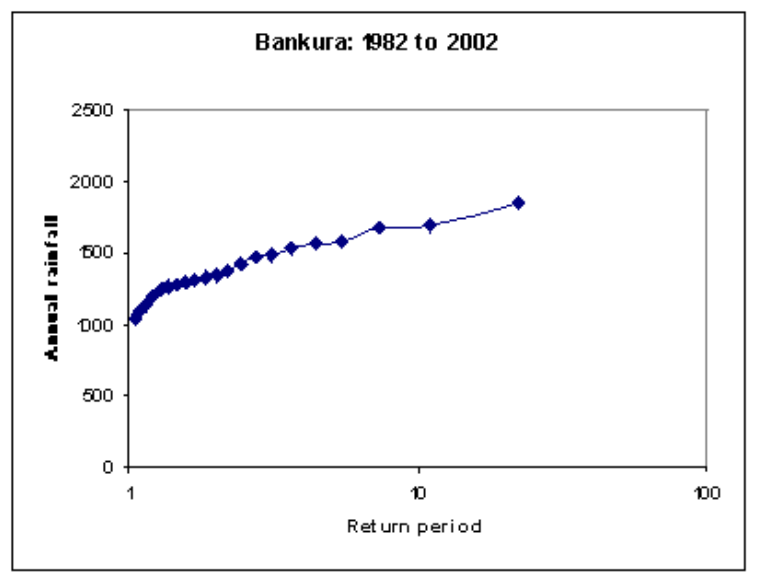

a

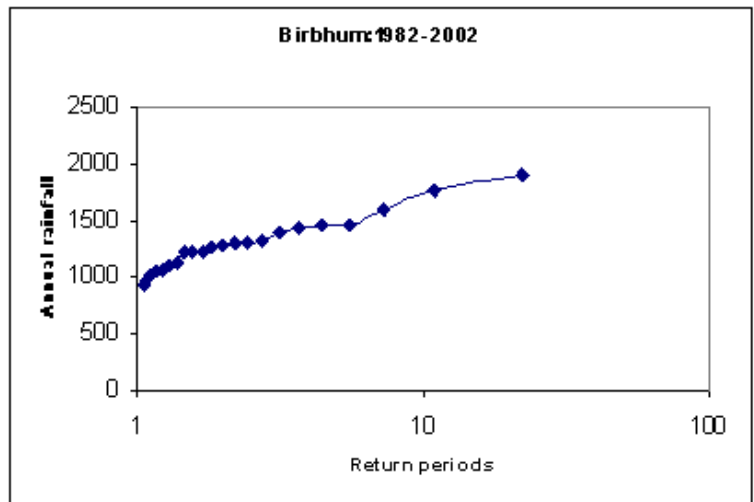

c intensities during the flood period and the respective return period is calculated with the aid of the graph obtained.

The return period of the years of heavy rainfall in 1956, 1959 and 1978 are all interpolated from the graphs shown in Figure 4.

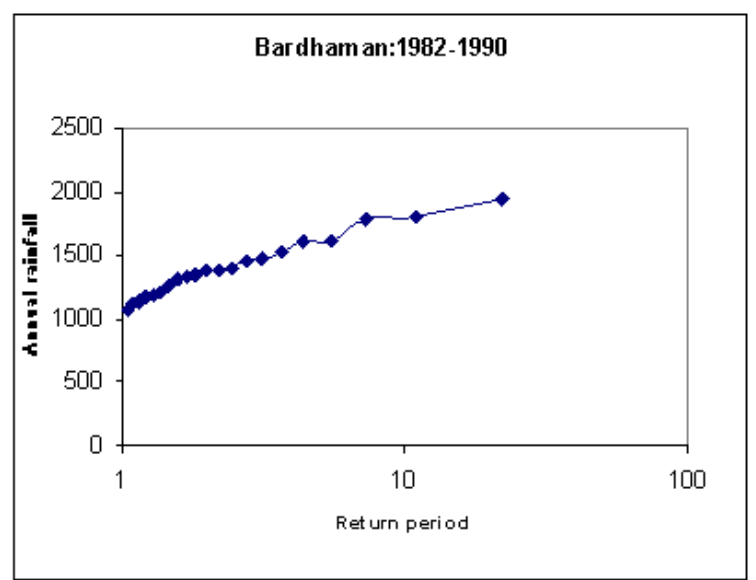

\section{$\mathrm{b}$}

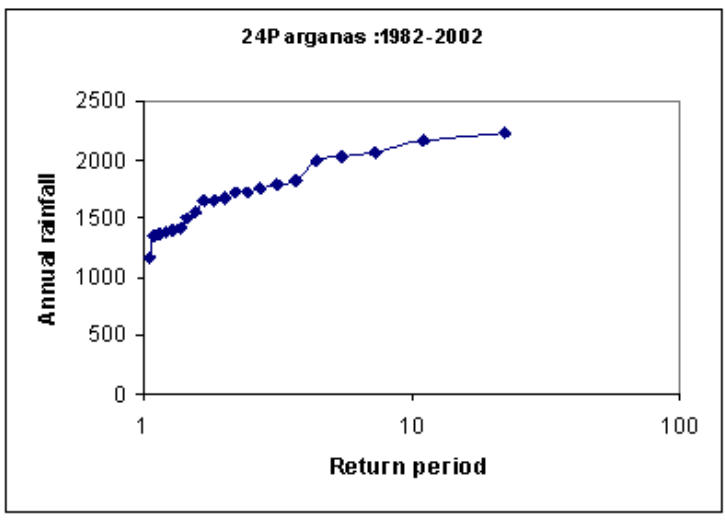

d

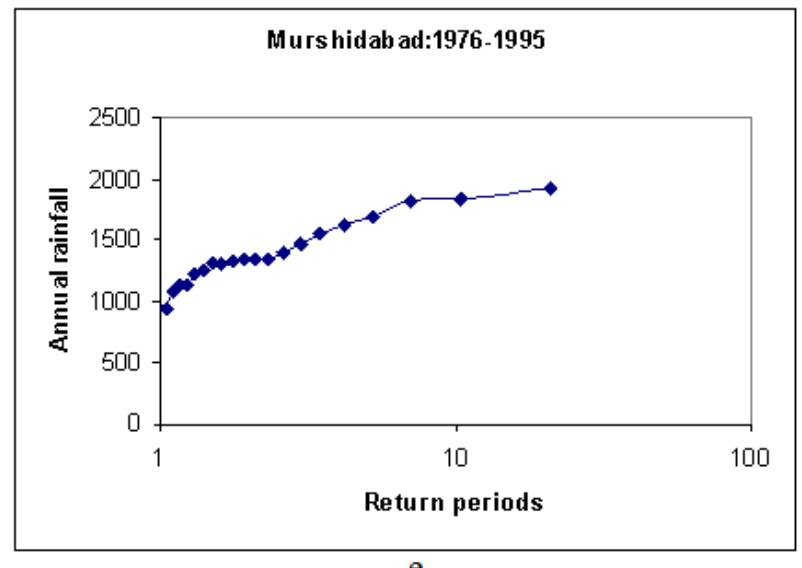

e

Figure 4. Representation of the expected return periods and probability of occurrences of rainfall event [Rainfall (mm) \& Return period (Year)]

\subsubsection{Mathematical Representation of Artificial} Neural Network

An (ANN) is a flexible mathematical structure that is capable of identifying complex nonlinear relationships between input and output data sets [25]. The ANN model of a physical system (Figure 5 ) can be considered with $n$ input neurons $\left(\mathrm{x}_{1}, \mathrm{x}_{2} \ldots \mathrm{x}_{\mathrm{n}}\right)$,h hidden neurons $\left(\mathrm{z}_{1}, \mathrm{z}_{2} . . \mathrm{z}_{\mathrm{n}}\right)$ and $\mathrm{m}$ output neurons $\left(\mathrm{y}_{1}, \mathrm{y}_{2} \ldots \mathrm{y}_{\mathrm{n}}\right)$. Let $\mathrm{t} j$ be the bias for neuron $\mathrm{z}_{\mathrm{j}}$ and $f_{k}$ for neuron $y_{k}$. Let $w_{i j}$ be the weight of the connection from neuron $x_{i}$ to $z_{j}$ and beta is the weight of the connection $z_{j}$ to $y_{k}$. The function that ANN calculates is:

$$
y_{k}=g_{A}\left(\sum z_{j} b_{j k}+f_{k}\right) \ldots(j=1-h)
$$

In which,

$$
z_{j}=f_{A}\left(\sum x_{i} w_{i j}+t_{j}\right) \ldots(i=1-n)
$$

where $g_{A}$ and $f_{A}$ are the activation functions [28]. 


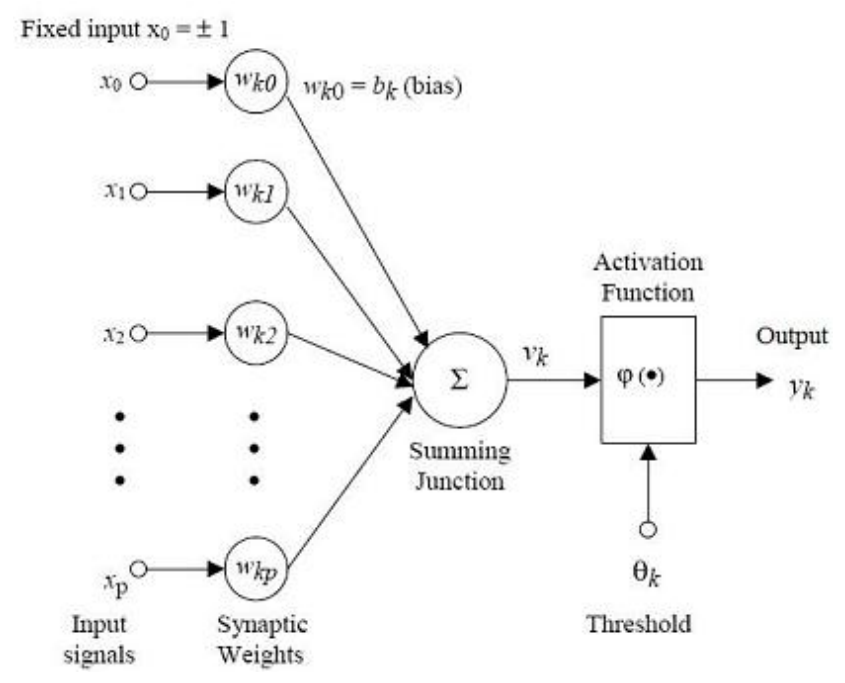

Figure 5. A Schematic Diagram of Artificial Neural Network
The network building procedure is divided into 3 phases which are described next in a broad way.

\subsection{Network Building Procedure}

\subsubsection{Selection of Network Topology}

Neural networks can be of different types, like feed forward, radial basis function, time lag delay etc. The type of the network is selected with respect to the knowledge of input and output parameters and their relationship. Once the type of network is selected, selection of network topology is the next concern [29]. Trial and error method is generally used for this purpose but many studies now prefer the application of genetic algorithm [30]. Genetic algorithms are search algorithms based on the mechanics of natural genetic and natural selection [31]. The basic elements of natural genetics - reproduction, crossover, and mutation - are used in the genetic search procedure. A GA can be considered to consist of the following steps [32]:

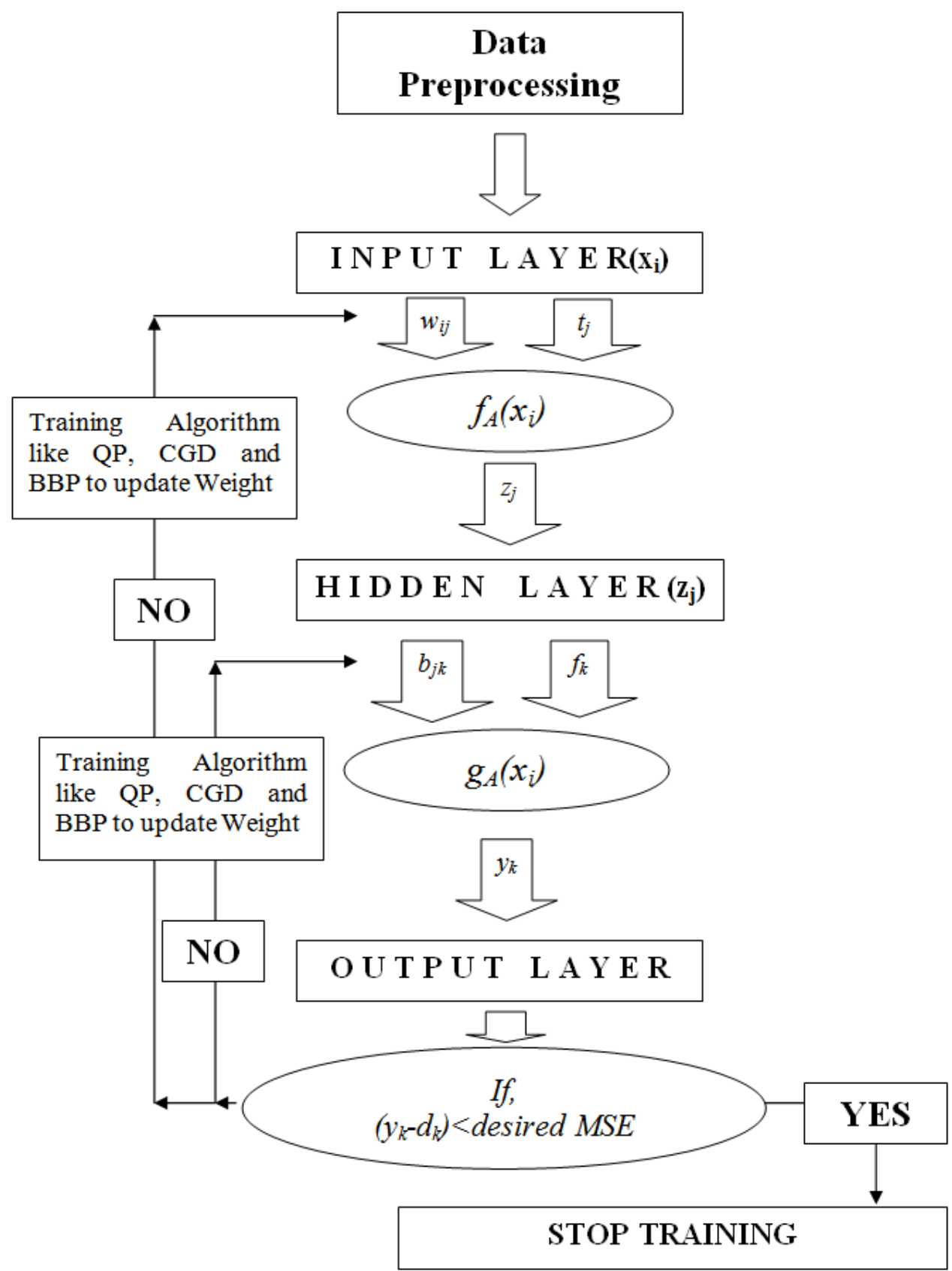

Figure 6. Chart showing model development methodology of ANN [Modified 34] 
1. Select an initial population of strings.

2. Evaluate the fitness of each string.

3. Select strings from the current population to mate.

4. Perform crossover (mating) for the selected strings.

5. Perform mutation for selected string elements.

6 . Repeat steps $2-5$ for the required number of generations.

Genetic algorithm is a robust method of searching the optimum solution to complex problems like the selection of an optimal network topology where it is difficult or impossible to test for optimality. The basics of GA have already been discussed by many authors [23,30,33]. Hence the details of the basic procedures of GA are not focused in the present paper and the model development methodology of ANN is shown in Figure 6.

Training Phase

To encapsulate the desired input output relationship, weights are adjusted and applied to the network until the desired error is achieved. This is called as "training the network". There is innumerable number of "training the network” algorithms like Quick Propagation (QP), Conjugate Gradient Descent (CGD), Batch Back Propagation (BBP) etc. Testing Phase

After training is completed, some portion of the available historical dataset is fed to the trained network and known output is estimated out of them. The estimated values are compared with the target output to compute the MSE. If the value of MSE is less than 1\%, the network is said to be sufficiently trained and ready for estimation. The dataset is also used for cross-validation to prevent over-training during the training phase [28].

\section{Results and Discussion}

\subsection{Rainfall Pattern and Its Variation in the Flood Prone Areas during the Years}

It may be recalled in recent memory the floods in the year of 1956, 1959, 1978, 1995, 1999 and 2000 are considered to be the years of severe floods in the southern districts and the rainfall patterns in some pertinent years of heavy precipitation in southern Bengal are described here:

1956: There was a concentrated and accumulated rainfall over gangetic west Bengal particularly in the lower catchment area of the Damodar, Ajoy and Mayurakshi during the period of $20^{\text {th }}$ to $27^{\text {th }}$ September, 1956. A low pressure area was formed and it moved into the north bay of Bengal on the $20^{\text {th }}$ of September. It developed into a depression at the head of the bay at on the afternoon of $22^{\text {nd }}$. Under the influence of this disturbance fairly widespread rain occurred over gangetic west Bengal and neighborhood during the period of $20^{\text {th }}$ to $27^{\text {th }}$, the rainfall being very heavy at places during $26^{\text {th }}$, $27^{\text {th }}$ and $28^{\text {th }}$ also.

1959: The year of 1959 experienced two periods of heavy rainfall covering the catchment of the rivers in central, western and southern districts of he state. The first spell occurred from $8^{\text {th }}$ to $12^{\text {th }}$ September while the second one from $30^{\text {th }}$ September to $3^{\text {rd }}$ October. In the later spell, there was heavy rain associated with a severe cyclonic storm formed in the east central bay of Bengal. On the morning of September $30^{\text {th }}$ it intensified into a severe storm. It then started to move northwestwards and crossed the west Bengal, Orissa coast. Under its influence heavy rainfall occurred in the gangetic west Bengal including lower Damodar basin.

1978: The year 1978 was a year of severe floods for the southern districts of the state when these areas faced the onslaughts of the subsequent cyclonic storms accompanied with heavy rainfall. The rainfall in the spell during the period of $31^{\text {st }}$ august to $3^{\text {rd }}$ September was due to a depression overland that moved from east to west from Midnapore to Daltonganj in Palamu districts of Bihar and route to Bankura and Purulia districts and four torrential rain occurred in four districts of the state. The storm rainfall in the second spell was much more severe and affected the entire gangetic west Bengal. Heavy rainfall also occurred in the upper catchment areas of the Mayurakshi, Ajoy and Damodar basins. The depression persisted for a long spell resulting in the continuous precipitation in the southern districts from $26^{\text {th }}$ September to $1^{\text {st }}$ of October. The Alipore observatory recorded a rainfall of $735.3 \mathrm{~mm}$ during this period, the maximum rainfall in the 24 hours being $369.6 \mathrm{~mm}$. The peculiarity of 1978 storm in the two spells was that the coastal areas received less rainfall than the interior parts.

1995: Year 1995 also happened to be a year of intense heavy rainfall resulting in the swelling of almost all the rivers of the state starting from Malda and Dinajpur districts in the north to the districts in the south. On $24^{\text {th }}$ September a depression was formed in North West Bay of Bengal which intensified further and after crossing West Bengal and Orissa coast laid centered over the Bihar state plateau. Under its influence, heavy rainfall resulted in almost all the catchment basins.

1999: Year 1999 happened to be a year of one of the worst precipitations in the history when most of the rivers in the state were in spate; reservoirs were up to their fullest capacity and the rivers unable to maintain the flow within their banks spilled in the adjoining areas. A depression formed over the east central bay and its neighborhood on $15^{\text {th }}$ October 1999 moving in south west direction it intensified into a severe cyclonic storm by $16^{\text {th }}$ midnight. The storm weakened into a low pressure area over the gangetic west Bengal and adjoining areas of Bihar state and became less marked on $20^{\text {th }}$ over the area but upper air circulation persisted over west Bengal. Under the influence of this system the gangetic west Bengal had heavy rains in the places on $18^{\text {th }}$ and $19^{\text {th }}$, at many places on the $22^{\text {nd }}$. Heavy to very heavy rainfall occurred on $19^{\text {th }}$ of this year.

2000: Consequent on the development of a low pressure in the Bihar plateau region the south Bengal districts experienced unprecedented heavy rainfall in the tributaries of Bhagirathi namely Pagla, Bansloi, Mayurakshi-Babla system, Ajoy, Damodar, etc. Such type of rainfall was never experienced in recent history. Rainfall during the brief spell of three days even exceeded the total annual rainfall. Such type of rainfall was thus tremendously high in magnitude and intensity and cast a wet blanket in the districts of Bardhaman, Bankura, Birbhum, Murshidabad and the 24- Parganas. It also resulted in the heavy swelling of the rivers as mentioned above.

The distribution of rainfall over the investigated flood years in these districts and the maximum and the minimum of all the years is calculated and then their average value is presented in Table 1-Table 5. The average value for all these years is comparatively much 
higher than any other year in consideration. The standard deviation of all the mean values is found to explore a better understanding of the range distribution pattern of rainfall in the flood affected years:

Table 1. Statistical details of rainfall event during the flood years

\begin{tabular}{|c|c|c|c|c|}
\hline \multicolumn{2}{|c|}{ Murshidabad } & & & Minimum (mm) \\
\hline Years & Mean (mm) & Maximum (mm) & & \\
\hline & & & 5.97 & \\
\hline 1956 & 201.405 & 396.84 & 0 & 29.51179 \\
\hline 1957 & 213.15 & 426.3 & 1.08 & \\
\hline 1978 & 213.82 & 426.56 & 1.46 & \\
\hline 1995 & 190.955 & 380.45 & 0.15 & \\
\hline 1999 & 213.4 & 426.65 & 1.67 & \\
\hline 2000 & 137.77 & 273.87 & & \\
\hline
\end{tabular}

Table 2. Statistical details of rainfall event during the flood years

\begin{tabular}{|c|c|c|c|c|}
\hline Birbhum & & & & Standard Deviation \\
\hline Years & Mean $(\mathrm{mm})$ & Maximum $(\mathrm{mm})$ & & \\
\hline & & & 3.6 & 0 \\
\hline 1956 & 188.15 & 372.7 & 0.9 & 50.31582 \\
\hline 1957 & 187.18 & 374.36 & 0.34 & \\
\hline 1978 & 278.935 & 556.97 & 0.01 & \\
\hline 1995 & 192.8 & 385.26 & 1.17 & \\
\hline 1999 & 205.32 & 410.63 & 241.8 & \\
\hline 2000 & 121.485 & & & \\
\hline
\end{tabular}

Table 3. Statistical details of rainfall event during the flood years

\begin{tabular}{|c|c|c|c|c|}
\hline Bankura & & & & \\
\hline Years & Mean (mm) & Maximum (mm) & Minimum (mm) & Standard Deviation \\
\hline & & & & \\
\hline 1956 & 174.39 & 346.3 & 2.48 & 0 \\
\hline 1957 & 138.05 & 276.1 & 0.95 & 51.65515 \\
\hline 1978 & 249.425 & 497.9 & 0 & \\
\hline 1995 & 198.1 & 396.2 & 0 & \\
\hline 1999 & 229.1 & 458.2 & 1.1 & \\
\hline 2000 & 116 & 230.9 & & \\
\hline
\end{tabular}

Table 4. Statistical details of rainfall event during the flood years

\begin{tabular}{|c|c|c|c|c|}
\hline \multicolumn{2}{|c|}{ Bardhaman } & & & Standard Deviation \\
\hline Years & Mean $(\mathrm{mm})$ & Maximum $(\mathrm{mm})$ & & \\
\hline & & & & \\
\hline 1956 & 168.7 & 334.5 & 0 & 6.9 \\
\hline 1957 & 166.85 & 333.7 & 0.7 & \\
\hline 1978 & 307.35 & 614 & 0.26 & \\
\hline 1995 & 217.03 & 433.8 & 0 & \\
\hline 1999 & 233.75 & 467.5 & 245 & 1.5 \\
\hline 2000 & 123.25 & 245 & & \\
\hline
\end{tabular}

Table 5. Statistical details of rainfall event during the flood years

\begin{tabular}{|c|c|c|c|c|}
\hline \multicolumn{2}{|c|}{ 24-Parganas } & & & \\
\hline Years & Mean (mm) & Maximum (mm) & Minimum (mm) & Standard Deviation \\
\hline 1956 & 198.7 & 396.6 & 0.8 & \\
\hline 1957 & 242.6 & 485 & 0.2 & \\
\hline 1978 & 401.125 & 802.2 & 0.05 & 99.6209 \\
\hline 1995 & 280.23 & 560 & 0.46 & \\
\hline 1999 & 354.06 & 707.8 & 0.32 & \\
\hline 2000 & 130.455 & 258.7 & 2.21 & \\
\hline
\end{tabular}

The above tables shown are the representation of the distribution of rainfall in the flood affected years. As observed from these Tables, the standard deviation is increasing for the places from Murshidabad to 24Parganas. A higher value of standard deviation means that there will be a wide range of the values of rainfall and it will be more deviated from the mean value while a low value of the deviation reveals low range of values and will be closer to the mean value. Thus Murshidabad has a fairy uniform distributed rainfall pattern during the years under consideration and the maximum variation and hence the 
maximum erratic rainfall occurred in the 24-Parganas during the flood years.

\subsection{Rainfall Runoff and Flood Analysis}

The districts in the southern parts of the state namely the gangetic West Bengal during the years 1956, 1959, 1978, 1995, 1999 and 2000 experienced heavy precipitation particularly in the months of September and October consequent upon low pressure/depressions developed in the Bay of Bengal. The years which faced such worst type of rainfall are 1956, 1959, 1978, 1995, 1999 and 2000. The year 2000 may be designated as the year of worst precipitation in terms of quantum, intensity and duration. Using the help of Strange's table [20], the runoff from the precipitation recorded is calculated along with the rainfall and runoff graph. The Table 6 shown below gives an idea of the intensity of rainfall and the prediction of the time in which the same intensity of rainfall may occur in the near future in the places under consideration. The extreme value of the intensity of rainfall has been taken as $100 \mathrm{~mm} /$ hour and the rainfall intensity equal to or less than that value measured in the rain gauge stations in the some particular years are listed in the Table 6 during the flood years at the five districts.

Table 6. Details of extreme event during the flood years at the five districts

\begin{tabular}{|c|c|c|c|c|}
\hline District & Gauge station & Flood year recorded & Return period (years) & Extreme event $(<100 \mathrm{~mm} / \mathrm{hour})$ \\
\hline \multirow{4}{*}{ Murshidabad } & \multirow[t]{2}{*}{ Ajamgunj } & 1956 & 5.73 & 88 \\
\hline & & 1995 & 2.9 & 82 \\
\hline & \multirow[t]{2}{*}{ Beherampur } & 1959 & 4.7 & 98 \\
\hline & & 1978 & 7 & 96.9 \\
\hline \multicolumn{5}{|c|}{ Rainfall to Runoff statistical relationship is : $\mathrm{R}=0.987 \mathrm{P}-10.32$ and the value of $\mathrm{r}^{2}=0.735$} \\
\hline District & Gauge station & Flood year recorded & Return period (years) & Extreme event $(<100 \mathrm{~mm} / \mathrm{hr})$ \\
\hline \multirow[t]{5}{*}{ Bardhaman } & Panagarh & 1978 & 22.7 & 80 \\
\hline & \multirow[t]{2}{*}{ Maithon } & 1999 & 5.5 & 68 \\
\hline & & 2000 & 7.33 & 95.4 \\
\hline & \multirow[t]{2}{*}{ Durgapur } & 1999 & 3.5 & 40 \\
\hline & & 2000 & 1.54 & 30 \\
\hline
\end{tabular}

Rainfall to Runoff statistical relationship is : $\mathrm{R}=0.7363 \mathrm{P}-13.971$ and the value of $\mathrm{r}^{2}=0.999$

\begin{tabular}{|c|c|c|c|c|}
\hline District & Gauge station & Flood year recorded & Return period (years) & Extreme event $(<100 \mathrm{~mm} / \mathrm{hr})$ \\
\hline \multirow{10}{*}{ Birbhum } & \multirow[t]{3}{*}{ Suri } & 1956 & 10.72 & 100 \\
\hline & & 1978 & 23 & 98 \\
\hline & & 2000 & 1.22 & 80 \\
\hline & \multirow[t]{4}{*}{ Rampurhat } & 1956 & 8.77 & 81.33 \\
\hline & & 1959 & 6.73 & 72 \\
\hline & & 1995 & 1.83 & 77.33 \\
\hline & & 2000 & 1.16 & 96.7 \\
\hline & Tantloi & 1999 & 4.4 & 85.5 \\
\hline & Tilpara & 2000 & 0.9 & 90 \\
\hline & Nalhati & & 1.83 & 78.22 \\
\hline \multicolumn{5}{|c|}{ Rainfall to Runoff statistical relationship is : $\mathrm{R}=0.652 \mathrm{P}-1$ and the value of $\mathrm{r}^{2}=0.9998$} \\
\hline District & Gauge station & Flood year recorded & Return period (years) & Extreme event $(<100 \mathrm{~mm} / \mathrm{hr})$ \\
\hline \multirow{3}{*}{ Bankura } & Bankura & 1959 & 2.15 & 70 \\
\hline & Mukutmanipur & 1978 & 21.9 & 68.44 \\
\hline & Phulberia & 1999 & 4.4 & 55 \\
\hline \multicolumn{5}{|c|}{ Rainfall to Runoff statistical relationship is : $\mathrm{R}=0.91 \mathrm{P}-4$ and the value of $\mathrm{r}^{2}=0.631$} \\
\hline District & Gauge station & Flood year recorded & Return period (years) & Extreme event $(<100 \mathrm{~mm} / \mathrm{hr})$ \\
\hline \multirow{5}{*}{ 24-Parganas } & \multirow[t]{3}{*}{ Alipore } & 1956 & 3.64 & 51 \\
\hline & & 1959 & 4.32 & 68.7 \\
\hline & & 1978 & 21.8 & 97.22 \\
\hline & \multirow[t]{2}{*}{ Dumdum } & 1978 & 19 & 80.48 \\
\hline & & 1995 & 3.7 & 49.3 \\
\hline
\end{tabular}

In all the above cases the value of $\mathrm{r}^{2}$ is between 0.6 and 1.0. This indicates a good correlation

\subsection{Flood Analysis}

West Bengal has 37,660 sq. km flood prone area spread over 111 blocks where the total geographical area of the state is $88,752 \mathrm{sq}$. $\mathrm{km}$. The statistics of flood that occurred during last 45 years (from 1956 - 2000) shows that only on 5 occasions the state has not faced any severe flood. The total devastated area crossed 20,000 sq. $\mathrm{km}$ in 4 different years and the flood of medium magnitude i.e. between 2,000 to $10,000 \mathrm{sq}$. $\mathrm{km}$. occurred on 10 occasions [35]. The North Bengal regions (mainly three districts) where 2500 to $4000 \mathrm{~mm}$ of rainfall occurs annually $80 \%$ of which are due to the monsoon winds. It rains 110 days in a year here; 200 to $300 \mathrm{~mm}$ of rainfall in 2 hours have even been recorded. 
The rainfall in gangetic planes are divided in three parts:

1. Bankura, Purulia, Bardwan, Birbhum and Murshidabad districts are less prone rainfall areas where annual rainfall is on an average 1140 to $1400 \mathrm{~mm}$.

2. Nadia, Hoogly, Midnapore, North-24 Parganas are medium rainfall accounting for 1400 to $1650 \mathrm{~mm}$ annually.

3. Howrah, South-24 Parganas has the highest with 1650 to $1900 \mathrm{~mm}$ annually.

4. $3945 \mathrm{~mm}$ in Jalpaiguri, $1285 \mathrm{~mm}$ in Birbhum, North Dinajpur records $1577 \mathrm{~mm}$ and South Dinajpur

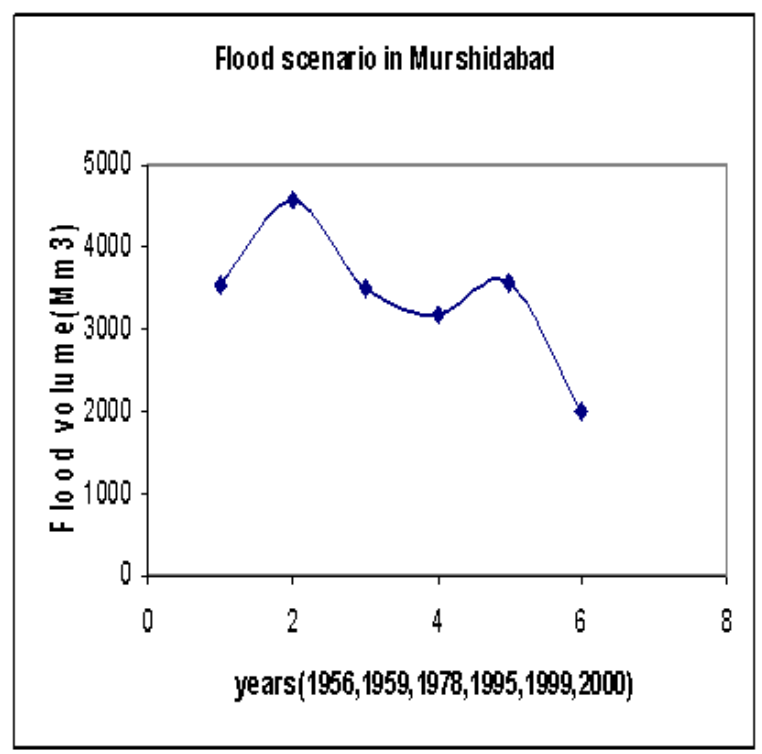

a

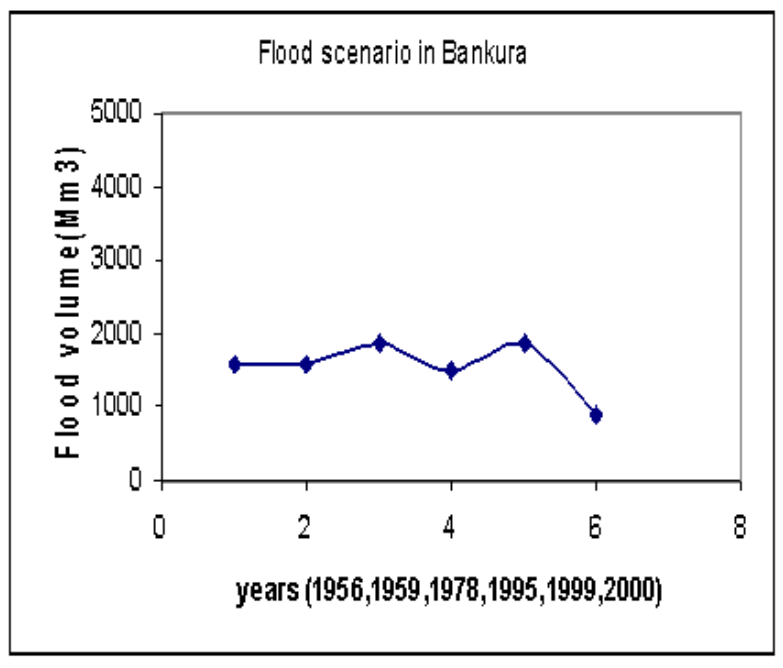

c
$1818 \mathrm{~mm}$ and Malda records $1540 \mathrm{~mm}$ on an average annually.

It gathers reasonably well from the above data that for a small state, there occurs quite a lot of rainfall. Along with rainfall there is also the presence of cyclonic winds and showers which is the reason for the ruckus caused annually in West Bengal especially places like Midnapore and South-24 Parganas. The floods volume during the years 1956, 1959, 1978, 1995, 1999 and 2000 are shown in Figure 7 and in the months of September and October, the rainfall intensity, magnitude and duration was found to be maximum.
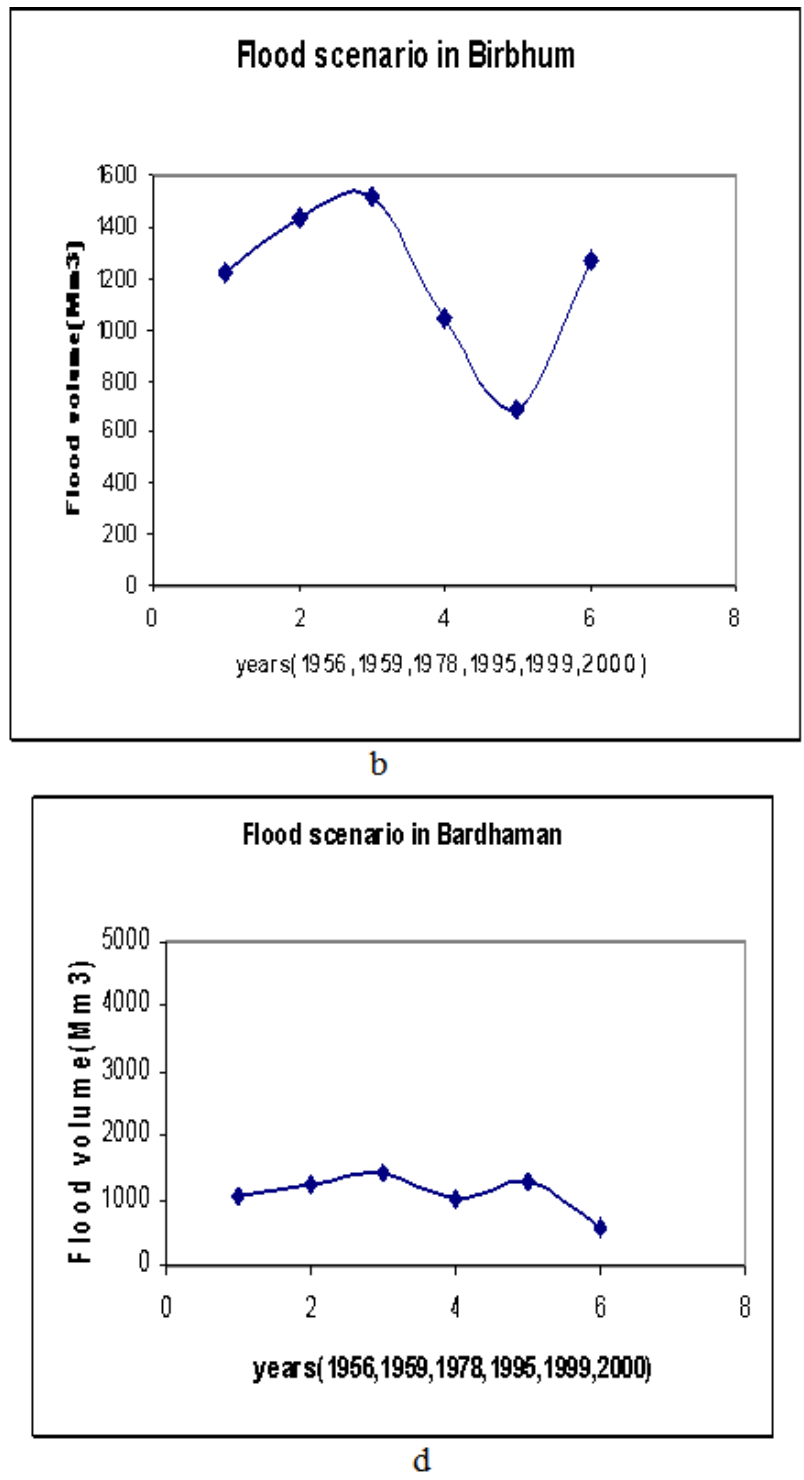

Figure 7. Flood scenario at the flood-prone districts during the years: 1956, 1959, 1978, 1995, 1999, 2000

\subsection{Lack of Control Structure and Reason for High Runoff in $\mathbf{2 0 0 0}$ Flood}

The ground slope of the basin areas out falling on the right of the Bhagirathi-Hoogly is from west to south east direction. During the monsoon at high stage all the rivers are fed by the Ganga-Padma flood discharge even on the normal flood. The volumes of runoff were so high that some of the rivers were unable to carry those runoffs between the river banks and also in between their flood embankments, where these existed [36]. All the rivers overflowed breaching their embankments. The total flood volume of the right bank rivers came down from the higher ground level to the lower level of the Bhagirathi, which for some duration of time had become nothing but a reservoir. The flood created due to the rainfall assumed the proportion of disaster because of the cumulative adverse features in the shape of:

- All the rainfall occurred during September when the soil moisture was high resulting in high runoff volume.

- The rainfall intensities at many places, particularly in the upper catchments of the Pagla-Bansloi, the Dwarkha-Bramhani and the Mayurakshi were very high. 
- The rainfall was widespread and the peak flood reached the outfall at the Bhagirathi in such sequence that all the peaks had synchronized, thereby the Bhagirathi with its limited capacity was simply non existent as drainage artery, it rather became an enormous reservoir with very high storage level, pushing the flood to further areas in the east.

- The Bhagirathi-Hoogly witnessed a high monsoon tide when the flood of its upper catchment was reaching the outfall at the lower reaches in the Hoogly district, thus delaying the flood evacuation resulting in the intensification of adverse condition in the upper reaches.

\subsection{Neuro-genetic Models}

A neuro-genetic models was developed to identify the relationship between return period and extreme rainfall [37] and the same approach has been applied in the present model with different boundary conditionsThe available dataset was divided and marked for training, testing and cross validation where $68.18 \%$ of the data set was applied for training and $15.91 \%$ of dataset were used as cross validation and testing purpose. Input and output parameters were scaled by $0.00672 \& 0.02424$ factor respectively. Table 7 shows the training, testing and cross validation MSE \& average error and topology of the networks.

Table 7. The Network Parameters of the Developed Neuro-genetic Models

\begin{tabular}{|c|c|c|c|}
\hline Network Name & QP & CGD & BBP \\
\hline \multicolumn{4}{|l|}{ NETWORK TOPOLOGY } \\
\hline Network type & $\begin{array}{l}\text { feed-forward fully } \\
\text { connected network }\end{array}$ & $\begin{array}{l}\text { feed-forward fully } \\
\text { connected network }\end{array}$ & $\begin{array}{l}\text { feed-forward fully } \\
\text { connected network }\end{array}$ \\
\hline Number of inputs & 1 & 1 & 1 \\
\hline Number of hidden layers & 2 & 2 & 1 \\
\hline Hidden units in the 1st hidden layer & 2 & 3 & 1 \\
\hline Hidden units in the 2nd hidden layer & 1 & 1 & 0 \\
\hline Number of outputs & 1 & 1 & 1 \\
\hline Connection Weight & 5 & 7 & 2 \\
\hline \multicolumn{4}{|l|}{$\begin{array}{l}\text { All the topology was created using genetic algorithms } \\
\text { with following parameters }\end{array}$} \\
\hline Population size & 60 & 60 & 50 \\
\hline Number of generations & 50 & 50 & 50 \\
\hline Network size penalty & 6 & 6 & 5 \\
\hline Crossover rate & 0.8 & 0.8 & 0.9 \\
\hline Mutation rate & 0.2 & 0.2 & 0.2 \\
\hline \multicolumn{4}{|l|}{ TRAINING ALGORITHM AND PARAMETERS } \\
\hline Training algorithm & $\begin{array}{c}\text { Incremental Back } \\
\text { Propagation }\end{array}$ & Batch Back Propagation & Levenberg-Marquardt \\
\hline Training Iteration & 50 & 50 & 50 \\
\hline \multicolumn{4}{|l|}{ STOP TRAINING CONDITIONS } \\
\hline MSE on training subset must drop below : - & 0.01 & 0.01 & 0.01 \\
\hline Maximum allowed number of iterations : - & 100000 & 100000 & 100000 \\
\hline Training stop reason : - & $\begin{array}{l}\text { Generalization loss became } \\
\text { too high }\end{array}$ & $\begin{array}{l}\text { Generalization loss became } \\
\text { too high }\end{array}$ & $\begin{array}{l}\text { Error reduction became too } \\
\text { low }\end{array}$ \\
\hline \multicolumn{4}{|l|}{ TRAINING \& TESTING RESULTS } \\
\hline Average MSE(Training) & 1.44 & 11.84 & 0.09 \\
\hline Average MSE (Testing) & 35.94 & 15.38 & 0.18 \\
\hline \multicolumn{4}{|l|}{ ESTIMATED RESULTS } \\
\hline MSE & 0.08 & 0.26 & 0.03 \\
\hline $\mathrm{R}$ & 0.988 & 0.98 & 0.99 \\
\hline C.E & 0.987 & 0.988 & 0.99 \\
\hline STDEV & 0.916 & 1.11 & 0.21 \\
\hline
\end{tabular}

As described in the methodology, the neuro-genetic model was trained with the help of BBP, CGD and QP algorithms from which the model with best training algorithm was selected for estimation. According to the results, the average MSE after training for BBP network was $0.09 \%$ which is $16 \%$ and $131.55 \%$ lesser than respectively for QP \& CGD networks. The average MSE after testing for BBP was 0.18 which is $399.33 \%$ and $170.88 \%$ less than the other two networks which forced the authors to select the network trained with BBP algorithm.

The predicted results from BBP was found to be $11.5 \%$ more accurate than CGD and 37.5\% more than QP and again the same training algorithms are found to be $22.9 \%$ \& 5.28 times more deviated than BBP.BBP model is also 0.99 times more efficient than CGD and 99.69\% more than QP. According to the performance validation criteria, BBP is selected as the best model out of the three. The estimated results were used to generate a relationship curve between return period and extreme events. According to the relationship curve a log-normal relationship was observed between return period and extreme events of West Bengal. The curve (Figure 8) also explains that an extreme event which may be 10 times more than the maximum rainfall event of West Bengal could occur only after 25.76 years which shows that Bengal may observe very frequent extreme events which would be more extreme than presently.

But rainfall which was less than 10 times the present minimum had a return period of 0.62 years as estimated by the neuro-genetic model. The estimated results implied that Bengal could observe extreme events of small 
magnitude within 1 year or 2 (recent) but in near future (after 25 years) the region may face severe rainfalls which may change the present geo-morphology of West Bengal. Though the model developed in the present study showed an approach to estimate a relationship between rainfall and their return period to show the present pattern of Bengals climatic extremities, the presentation could be improved by including some more causal variables.

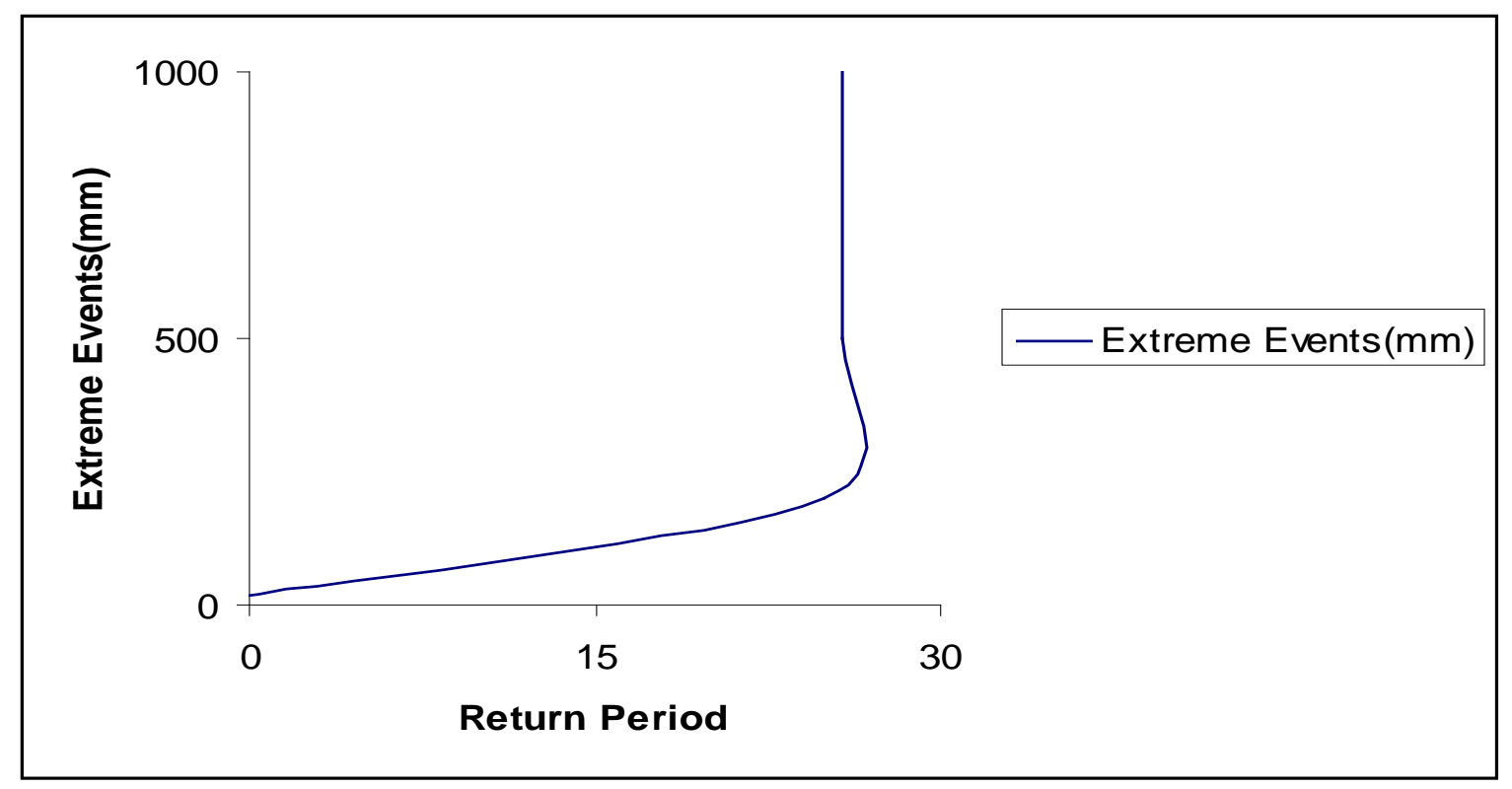

Figure 8. Extreme event (mm) vs Return period obtained from neuro genetic model

\section{Conclusion}

The major flood prone and flood affected five districts are considered in the present study viz. Birbhum, Bankura, Bardhaman, 24-Parganas and Murshidabad where the flood situation in the years 1956, 1959, 1978, 1995, 1999, 2000 have been analyzed using the neuro-genetic model. The analysis in part included the statistical representation of the rainfall pattern and flood scenario (Figure 7) in the above districts, for different return periods. The intensity of maximum rainfall has been assumed as $100 \mathrm{~mm} /$ hour and the return period of the rainfall in those places having intensity less than or equal to $100 \mathrm{~mm} / \mathrm{hr}$ has been determined. The minimum return period having a value of 0.9 years and the maximum having a value of 22.7 years is observed in case of Suri, Birbhum and Panagarh, Bardhaman respectively. The analysis of the flood pattern over the years has yielded illuminating results regarding its shear capacity especially in the years 1978, 1999 and 2000. This led to the loss of many lives and properties and the results revealed the high occurrence of future flood with disastrous consequences. Thus based on the dynamical behavior of the weather pattern, extreme rainfall during the monsoon months might be responsible for increasing the flood frequencies. This study suggests that much of the flood related damages in recent decades might be due to the increased frequency of extreme weather events, for which measures are to be taken to reduce flood vulnerability, through proper land use planning following a sustainable development strategy. Further, unsustainable land use such as rapid urbanization and deforestation may be responsible for increasing floods damage and related death [10]. Concerning the flood events during these years, there are some fundamental questions which are required to be addressed for finding out a solution to this complex extreme events. In the basin of Mayurakshi, Ajoy, Jalagni, Churni, Ichamati, the affected area is a vast one covering the entire districts of Birbhum, Murshidabad, and Bankura, a part of Bardhaman and 24 Parganas. The flood management concept needs to be a radical one, where involvement and commitment of all concerned is an absolute necessity. Though the model developed in the present study showed an approach to estimate a relationship between rainfall and their return period to show the present pattern of Bengals climatic extremities, the presentation could be improved by including some more causal variables.

It is necessary to design for failure: in developing the strategy, explicit consideration should be given to the mode and consequences of failure, and how those will be managed. Thus, dike systems may be designed with weak points so that failure is likely to occur at the most manageable point. Decisions about the most appropriate flood management strategy to adopt must consequently both take account of the effects of climate change and the contribution of the flood management strategy to slowing climate change and then stabilizing the climate. Recognizing that water is a finite and vulnerable resource, differentiation between water resources management, flood management and drought management needs to be circumvented. Flood management plans need to be intertwined with drought management through the effective use of floodwater and/or by maximizing the "positive” aspects of floods.

\section{Acknowledgement}

All support for this study was provided by the Department of Civil Engineering, National Institute of Technology (NIT) Durgapur. The authors are grateful to Prof. Swapan Bhattacharya, the Director of NIT Durgapur for his continued encouragement towards the study of 
urban flood analysis using neuro-genetic model and Prof. Parthapratim Gupta, Dean (Research \& Consultancy) for financial support towards the data collection and field study. Also the authors want to thank Irrigation \& Waterways Dept., Govt. of West Bengal for providing necessary information and data in preparing the manuscript.

\section{References}

[1] Central Water Commission (CWC). "Manual on Flood Forecasting”, River Management Wing, New Delhi, 1989.

[2] Biswasroy M., Roy P.K, Samal N.R., Mazumdar, A. "Socioeconomic Valuations of Wetland Based Occupations of Lower Gangetic Basin through Participatory Approach”, Environment and Natural Resources Research, 2(4): 30-44, 2012.

[3] Sharma V. K. "Natural disaster management in national development- Indian perspective”, New united process publisher, 26: 32, 1997

[4] Dhar O.N., Nandargi S. "A study of floods in the Bramaputra basin in India”, Int. J. of Climatology, 20 ( 7-9):771-782, 2000.

[5] Samal N.R., Roy D., Mazumdar A., Bose B. "Influence of thermal stratification on dissolved oxygen in Subhas Sarobar”, Kolkata. J. Curr. Sci., 7 (1): 259-266, 2004.

[6] Samal N.R., Roy, P.K., Biswasroy, M. and Mazumdar, A. 2014. Limnological Comparisons of Threats to Aquatic Life Owing to Thermal Stratification in two Morphometrically Different Urban Shallow Lakes, Sustainability, Agri, Food and Environmental Research, 2(1): 13-30.

[7] Pal, M., Samal N.R., Roy, P.K. and Biswasroy, M. 2014. Temperature and dissolved oxygen stratification in the lake Rudrasagar: Preliminary investigations, Sustainability, Agri, Food and Environmental Research, 2(1): 1-12.

[8] Samal, N.R., Roy, D., Mazumdar, A. and Bose, B. 2004. Seasonal Response of Water Temperature of Rabindra Sarobar, the National Lake, in relation to $\mathrm{pH}$, Dissolved Oxygen, Biochemical Oxygen Demand and Chemical Oxygen Demand., Journal Public Health Enggs., Vol. 2004, No. 2, pp. 39-42.

[9] Mazumdar, A., Samal, N.R., Roy, D. and Gangopadhyay, A. 2007. Physico-Chemical Characteristics of Water in a shallow lake Rabindra Sarobar in Metropolis Kolkata, Journal of Inst. of Enggs. (IE-CH), India, vol. 88, pp. 32-40.

[10] Samal N.R., Mazumdar A. "Management of Lake Ecosystem". J. of The Ekologia (The Ekol.), 3(2), 123-130, 2005.

[11] Samal N.R., Roy P.K., Biswas M., Mazumdar A. "Summer thermal stratification: an indicator of water pollution in shallow lake”, J. Chem. Eng., Instit. Eng. (India), 90: 37-43, 2010.

[12] Pielke R.A. (Jr), Downton M.W. "Precipitations and damaging floods; trend in the U.S. - 1932-1997”. J. of climate, 15th Oct, 3625-3637, 2000.

[13] Szlafsztan C.F. "Analysis of the poverty, natural disaster relationship in the Buenos Aires (Argentina)", J. of Natural disaster, 23,2:1, 2001.

[14] De. U.S. "Extreme weather events and natural hazards", Leeward News. Jan-March, Newsletter, IMD, 1:10, 2004.

[15] Bryant Edward \& Allen Perry, "Climate Process and Change", Cambridge University press, 167, 1997.

[16] NMIWD, News Magazine of Irrigation \& Waterways Dept., "Sechpatra”, Govt. of West Bengal, June, Vol.1, No.1, 2001.

[17] Samal N.R., Matonse A.H. Mukundan R., Zion M.S., Pierson D.C., Gelda R.K., Schneiderman E.M. "Modeling potential effects of climate change on winter turbidity loading in the Ashokan Reservoir, NY”, Hydrological Processes.
[18] Samal N.R., Mazumdar A., Jöhnk K.D., Peeters F. “Assessment of ecosystem health of tropical shallow waterbodies in eastern India using turbulence model. Aquatic Ecosystem Health \& Management, 12: 215-225, 2009.

[19] Samal, N.R., Jöhnk, K.D., Peeters, F., Bäuerle, E., Mazumdar, A., 2008. Mixing and internal waves in a small stratified Indian Lake: Subhas Sarobar. In: Mohanty, P.K. (ed.) Monitoring and Modelling Lakes and Coastal Environments. Springer, Berlin, pp. 91-100.

[20] Samal, N. R. \& Mazumdar, A. 2005a. Artificial boundary effect on primary productivity of the littoral garden. Journal of Environmental Protection 25: 334-338.

[21] Samal N.R., Pierson D.C., Huang Y., Read J., Anandhi A., Owens E.M. "Impact of climate change on Cannonsville reservoir thermal structure in the New York City Water Supply", Water Quality Research Journal, Canada, vol. 47 (3-4), pp. 389-405, 2012.

[22] Goswami A.B. "Hydrological Status of West Bengal. In Changing Environmental Scenario of the Indian Subcontinent”. Ed. By S.R. Basu.ACB Publication, Kolkata, 299-314, 2002.

[23] Wang Q.J. "The genetic algorithm and its application to calibrating conceptual rainfall-runoff models”, J. Water Resour. Res. 27(9), 2467-2471, 1991.

[24] R. V. Ramana, B. Chakravorty, N. R. Samal, N.G. Pandey and P. Mani. 2008. Development of Intensity Duration Frequency curves using L-moment and GIS technique' Journal of Applied Hydrology, JAH Vol. XXI, No.1\&2: 88-100.

[25] Wang A.P., Liao H.Y., Kou C.H., Huang, C.Y. "Artificial neural networks on reservoir inflows forecasting during typhoon season A case in Taiwan", WSEAS Transactions on Mathematics 5 (4):416-422, 2006.

[26] Chow V.T., Maidment D.R., Mays L.W. "Applied hydrology”, International Edition. New York: MacGraw-Hill, 1988.

[27] Subramanya K. "Engineering Hydrology", Chapter-7, Tata McGraw-Hill Publishing, Company Limited, New Delhi. (2"d Edition), 1994.

[28] Sudheer K.P. "Knowledge Extraction from Trained Neural Network River Flow Models”, J. Hydrologic Engineering, 10(4): 264-269, 2005.

[29] Xu Z.X., Li J.Y. "Short-term inflow forecasting using an artificial neural network model”, John Wiley \& Sons, Ltd, 2001.

[30] Ahmed J.A., Sarma A.K. "Genetic Algorithm for Optimal Operating Policy of a Multipurpose Reservoir”, Journal of Water Resources Management, 19:145-161, 2005.

[31] Zhang Q., Stanley S.J. "Real-time treatment process control with artificial neural networks”, J. of Environmental Engineering, 125(2): 153-160, 1999.

[32] Burn D.H., Yulianti J.S. "Waste-load allocation using genetic algorithms”, J. Water Resource Planning and Management, ASCE 127(2): 121-129, 2001.

[33] Wardlaw R., Sharif M., "Evaluation of genetic algorithms for optimal reservoir system operation", J. of Water Resources Planning and Managementt, 125(1), 25-33, 1999.

[34] Biswasroy M., Roy P.K., Mazumdar A., Majumder M., Samal, N.R. Impact of Land Use and Aquatic Plants on the Water Quality of the Sub-Tropical Alpine Wetlands in India: A Case Study Using Neuro-Genetic Models, J. of Water Resource and Protection, 4:576-589, 2012.

[35] IWRS. "Theme Paper on Management of floods and droughts", Indian Water Resources Society, Roorkee, India, 4-12, 2001.

[36] Wei C.C., Hsu N.S. "Development of a real-time optimization model for flood control of a multipurpose reservoir", Journal of the Chinese Institute of Civil and Hydraulic Engineering 19 (3): 355-365, 2007.

[37] Yitian L., Gu R.R. "Modeling Flow and Sediment Transport in a River System Using an Artificial Neural Network", J. of Environmental Management, 31(1):122-134, 2003. 